\title{
Lactobacillus spp. Inhibit the Biofilm Formation of Pseudomonas aeruginosa
}

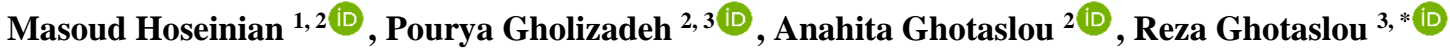 \\ 1 Hospital of Miyana, Tabriz University of Medical Sciences, Tabriz, Iran; hoseinianhhh@gmail.com (M.H.); \\ 2 Student Research Committee, Tabriz University of Medical Sciences, Tabriz, Iran; poorya.gholizadeh@ gmail.com (P.G.); \\ ghotaslouanna@gmail.com (A.G.); \\ 3 Microbiology Department, School of Medicine, Tabriz University of Medical Sciences, Tabriz, Iran; \\ rzgottaslo@yahoo.com (R.G.); \\ * Correspondence: rzgottaslo@yahoo.com;
}

Scopus Author ID 16686361200

Received: 1.03.2021; Revised: 28.04.2021; Accepted: 1.05.2021; Published: 9.05.2021

\begin{abstract}
Probiotic bacteria are microbial food supplements with beneficial properties on human health. This study aimed to isolate Lactobacillus spp. from the traditional homemade dairy and evaluate their inhibitory effects on the biofilm formation of P. aeruginosa. In this study, 10 samples of traditional homemade yogurt and milk samples were collected from five separated rural areas of Miyana, Azerbaijan, Iran, from May-June 2016. Lactobacillus spp. was isolated from traditional homemade dairy using microbiological methods. Finally, Lactobacillus spp. effects on P. aeruginosa biofilm were determined by the modified micro-plate test. Fifty-eight acid-tolerance bacteria were isolated from milk and yogurt samples. L. plantarum and L. casei had antibiofilm activity. The percentage of biofilm inhibition by $L$. plantarum and $L$. casei isolated from yogurt and milk were obtained zero to $52.1 \%$ and $5.7 \%$ to $48.8 \%$; and zero to $25.8 \%$ and $5.2 \%$ to $16.1 \%$, respectively. L. plantarum and L. casei isolated from traditional milk and yogurt have an inhibition effect on the biofilm formation of $P$. aeruginosa. It suggests the traditional homemade dairy is one of the best probiotics against biofilm-producing $P$. aeruginosa.
\end{abstract}

Keywords: lactic acid bacteria; probiotic bacteria; biofilm; antibiofilm activity; traditional dairy; Pseudomonas aeruginosa.

(C) 2021 by the authors. This article is an open-access article distributed under the terms and conditions of the Creative Commons Attribution (CC BY) license (https://creativecommons.org/licenses/by/4.0/).

\section{Introduction}

Traditional dairy products are homemade and natural products, which could be a valuable source of lactic acid bacteria [1,2]. These products are part of the daily diet of most people around the world. Lactic acid bacteria have fermentation activities that can result in the inhibition of pathogenic and spoilage bacteria. The antimicrobial effects of Lactobacillus spp. May result in the production of antimicrobial substances such as bacteriocins, lactic acid, diacetyl, and hydrogen peroxide [3-5]. The microbiological characteristic of several traditional dairy products have been studied in Iran [6-9] and other countries [10, 11]. Lactobacillus species are Gram-positive, non spore-forming, and catalase-negative bacilli, producing lactic acid as the main product of carbohydrates fermentation [12]. Lactobacillus spp. are presented in milk and dairy products such as yogurt, cheese, and fermented milk [13]. Lactobacillus spp. are used as a starter bacterium for different fermented foods [2]. P. aeruginosa is a Gramnegative and oxidase-positive bacillus isolated from various infections and is one of the most 
antibacterial resistant bacteria. The mortality rate of $P$. aeruginosa infections is $50 \%$ in cancer patients, patients with acquired immune deficiency syndrome, cystic fibrosis disease, and severe skin burns $[14,15]$. Biofilm formation causes the reduction of antibiotic susceptibility compared to planktonic cells in $P$. aeruginosa, which could play an important role in the pathogenesis of $P$. aeruginosa [16-18]. In Azerbaijan, traditional milk and yogurt are widely produced and consumed. At the same time, these products constitute a natural reservoir of Lactobacillus spp., which have not yet been studied their activity against $P$. aeruginosa. Several studies demonstrated the antibiotic and anti-biofilm effects of different genera of bacteria [19], foods [20,21], herbal extracts [22-24], and agents [25-28] on the biofilm formation and growth of $P$. aeruginosa. In the present study, Lactobacillus spp. isolated from the traditional homemade milk and yogurt were evaluated for biofilm inhibition activity against $P$. aeruginosa.

\section{Materials and Methods}

\subsection{Sampling.}

Five samples of traditional homemade yogurt and five samples of traditional homemade milk were collected from the rural area; in Miyana, Azerbaijan, Iran, from May-June 2018. The yogurt and milk samples were collected in sterilized bottles and transferred to the laboratory at $4^{\circ} \mathrm{C}$ and were stored at $4^{\circ} \mathrm{C}$. They were used in experiments [29].

\subsection{Isolation of bacteria and selection of acid-resistant isolates.}

One milliliter of each yogurt and milk sample was shaken and were suspended in 10 $\mathrm{mL}$ of sterilized peptone (Sigma, The USA) $(8.5 \mathrm{gr} / \mathrm{L} \mathrm{NaCl}$ (Sigma, The USA) and $1 \mathrm{gr} / \mathrm{L}$ peptone). One $\mathrm{mL}$ of each prepared suspensions was added to $10 \mathrm{~mL}$ of De Man, Rogosa, and Sharpe (MRS) broth medium (Biolife, Milano, Italy) and was incubated at $37^{\circ} \mathrm{C}$ for $24 \mathrm{~h}$ in microaerophilic and anaerobic condition (Mart microbiology B.V., The Netherland). Afterward, $1 \mathrm{~mL}$ of suspensions was added to phosphate buffer saline (PBS) under $\mathrm{pH}$ 2.5-3 and was incubated at $37^{\circ} \mathrm{C}$ for $2 \mathrm{~h}$. For detection of acid-resistant lactobacilli and to removing unwanted bacteria, PBS was centrifuged; the sedimentation was transferred to the MRS broth and was incubated at $37^{\circ} \mathrm{C}$ for $24 \mathrm{~h}$. The MRS broth was streaked on the MRS agar (Merck, German) at $37^{\circ} \mathrm{C}$ for $48-72 \mathrm{~h}$ in anaerobic condition. Finally, Lactobacillus spp. were identified by colony morphology, biochemical tests, Gram's staining, catalase reaction, growth at acidic medium, growth in MRS broth at $15^{\circ} \mathrm{C}$ and $37^{\circ} \mathrm{C}$, and carbohydrates fermentation patterns [30]. We also identified Lactobacilli by the API 50 CHL system (Biomerioux, France). All of the isolated strains were maintained at $-80{ }^{\circ} \mathrm{C}$ in the presence of $20 \%$ glycerol (Sigma, France).

\subsection{Determination of biofilm production by P. aeruginosa.}

The fresh overnight culture of $P$. aeruginosa (equal to 0.5 McFarland) was prepared. Fifty $\mu \mathrm{L}$ of the suspension was inoculated to $150 \mu \mathrm{L}$ of Trypticase soy broth (Merck, Germany) contains $3 \%$ glucose (Sigma, the USA) prepared in a sterile 96-well flat-bottomed plastic tissue culture plate with a lid. A well was considered as a negative control that contained TSB with 3 $\%$ glucose. The plate was incubated at $37^{\circ} \mathrm{C}$ for $48 \mathrm{~h}$. The wells were washed 3 times with 200 $\mu \mathrm{L}$ of PBS (pH 7.3). The biofilm produced was stained with $200 \mu \mathrm{L}$ crystal violet (Sigma, The USA) $0.5 \%$ at $37^{\circ} \mathrm{C}$ for $15 \mathrm{~min}$. The excess stain was decanted and washed 3 times with sterile 
deionized water and left to air dry. Two hundred $\mu \mathrm{L}$ ethanol $95 \%$ was added to the wells and shacked gently. The optic density (OD) of each well was measured at $492 \mathrm{~nm}$ by an ELISA reader (DANA, Iran) [28, 31].

\subsection{Determination of Lactobacilli inhibitory effect on P. aeruginosa biofilm.}

To determine the inhibitory effect of Lactobacillus spp. against $P$. aeruginosa biofilm, the modified micro-plate test was used as described by Stepanovic et al. [31]. Briefly, Overnight fresh culture of $P$. aeruginosa and Lactobacillus spp. (equal to $0.5 \mathrm{McFarland}$ ) was prepared; $50 \mu \mathrm{L}$ of the suspension of $P$. aeruginosa was inoculated to $100 \mu \mathrm{L}$ of TSB contains $3 \%$ glucose and $50 \mu \mathrm{L}$ of Lactobacillus spp. Were prepared in a sterile 96 -well flat-bottomed plastic tissue culture plate with a lid. The plate was incubated at $37^{\circ} \mathrm{C}$ for $48 \mathrm{~h}$. The wells were washed 3 times with $200 \mu \mathrm{L}$ of PBS (pH 7.3). The biofilm produced was stained with $200 \mu \mathrm{L}$ crystal violet $0.5 \%$ at $37^{\circ} \mathrm{C}$ for $15 \mathrm{~min}$. The excess stain was decanted and washed 3 times with sterile deionized water and left to air dry. Two hundred $\mu \mathrm{L}$ ethanol $95 \%$ were added to the wells and shacked gently. The OD of each well was measured at $492 \mathrm{~nm}$ by ELISA counter. Biofilm inhibition percent by Lactobacillus spp. was evaluated by biofilm inhibition percent = (OD control - OD treat) $* 100 /$ OD control. All experiments were done three times, and the answers were averaged.

\section{Results and Discussion}

Fifty-eight acid-tolerance bacteria were isolated from 10 samples. L. casei and $L$. saniviri were isolated from all milk and yogurt samples, follow as L. parabuchneri were the most isolated bacteria $(\mathrm{n}=9,15.51 \%)$ (Table 1). L. plantarum was isolated from milk samples of two villages as well as were isolated from yogurt samples of four villages. On other hands, L. case $i$ and L. plantarum were isolated from milk samples of five villages and two villages, respectively. Besides, $L$. case $i$ and $L$. plantarum were isolated from yogurt samples of 5 regions and 4 villages, respectively. L. plantarum and L. casei had antibiofilm activity.

The range of OD means for biofilm formation inhibition by L. plantarum and L. casei isolated from milk were recorded from 0.1 to 0.681 and 0.77 , respectively. The mean percentage for inhibition of biofilm formation by L. plantarum and L. casei isolated from milk were obtained $12.9 \%$ and $10.65 \%$, respectively. In the milk samples, $L$. plantarum had the most inhibition of biofilm formation (25.8\%), and L. casei had $16.1 \%$.

In addition, the range of means of OD for inhibition of biofilm formation by $L$. plantarum and L. casei isolated from yogurt were recorded from zero to 0.43933 and 0.46967 to 0.86967 , respectively. The mean percentage for inhibition of biofilm formation by $L$. plantarum and L. casei isolated from yogurt were $26.05 \%$ and $27.25 \%$, respectively. The results demonstrated that $L$. plantarum isolated from yogurt also had the most inhibition of biofilm formation $(52.1 \%$ ) and followed by L. casei $(48.8 \%)$.

Probiotic bacteria carry out various activities in hosts, such as normal flora, provide necessary vitamins and ingredients for hosts, and have broad-spectrum activity against pathogenic bacteria [32]. Lactic acid bacteria are associated with fermented foods and are used as starter cultures or probiotics in these foods [33]. Lactic acid bacteria play a main role in various dairy products $[1,34]$.

In this study, 58 bacterial isolates with probiotic potential from traditional milk and yogurt were isolated from five rural areas in Azerbaijan, Iran. These results are consistent with 
Abdelbasset et al. study that 52 lactic acid bacteria from 13 traditional fermented samples were isolated [35].

Table 1. The isolated bacteria from dairy products.

\begin{tabular}{l|c|c|c}
\multirow{2}{*}{ Bacteria } & $\begin{array}{c}\text { Milk } \\
\mathbf{N}(\%)\end{array}$ & $\begin{array}{c}\text { Yogurt } \\
\mathbf{N}(\boldsymbol{\%})\end{array}$ & $\begin{array}{c}\text { Total } \\
\mathbf{N}(\boldsymbol{\%})\end{array}$ \\
\hline L. acidifarinae & $1(4.34)$ & $2(5.71)$ & $3(5.17)$ \\
\hline L. brevis & $1(4.34)$ & 0 & $1(1.72)$ \\
\hline L. casei & $5(21.73)$ & $5(14.28)$ & $10(17.24)$ \\
\hline L. collinoides & $2(8.69)$ & $2(5.71)$ & $4(6.89)$ \\
\hline L. duranis & 0 & $1(2.85)$ & $1(1.72)$ \\
\hline L. frintoshensis & $2(8.69)$ & $2(5.71)$ & $4(6.89)$ \\
\hline L. mali & 0 & $2(5.71)$ & $2(3.44)$ \\
\hline L. manihotivorans & 0 & $3(8.57)$ & $3(5.17)$ \\
\hline L. parabuchneri & $5(21.73)$ & $4(11.42)$ & $9(15.51)$ \\
\hline L. paracasei & 0 & $3(8.57)$ & $3(5.17)$ \\
\hline L. plantarum & $2(8.69)$ & $4(11.42)$ & $6(10.34)$ \\
\hline L. rapi & 0 & $1(2.85)$ & $1(1.72)$ \\
\hline L. rosoiae & 0 & $1(2.85)$ & $1(1.72)$ \\
\hline L. saniviri & $5(21.73)$ & $5(14.28)$ & $10(17.24)$ \\
\hline Total & $23(100)$ & $35(100)$ & $58(100)$
\end{tabular}

Acid tolerance bacteria is the main indicator for probiotic bacteria [36], which created a difference between probiotic strains, was assessed by determining this aspect. The $\mathrm{pH}$ range is so important for the survival of Lactic acid bacteria [36, 37]. Since low $\mathrm{pH}$ is considered one of the main features of probiotic bacteria [37], a high acidic tolerance method was used to detect probiotic bacteria in the present study. Dairy products include high microbial diversity. Moreover, isolation of each of these strains is so time-consuming. Therefore, by acidifying an area, the non-probiotic strains were mostly removed. So, in our study, a selective screening method in acidic conditions was used. Since, from 10 cases of traditional homemade milk and yogurt, 14 species were isolated as an acid-resistant bacterium.

Lactobacillus spp. is the normal flora of the intestine. It plays an important role in human health by preventing intestinal infection, reducing cholesterol, stimulating the immune system, and reducing the risk of clone cancer [38]. Boris et al. identified that Lactobacillus spp. Isolated from dairy inhibit growing of $P$. aeruginosa, S. aureus, E. coli and $S$. typhimurium. The most inhibition effect was for S. aureus and E. coli [39]. Coconnier et al.'s study demonstrated that $L$. acidophilus possesses an inhibition effect on growing steps of various pathogenic bacteria, which are active in the urinary tract and vagina like $P$. aeruginosa. L. acidophilus reduces these organisms' attachment to epithelial cells and decreases the colony count of these bacteria [40].

In this study, L. casei and L. plantarum isolated from traditional milk and yogurt could inhibit the biofilm formation of $P$. aeruginosa. Among them, the most inhibition effect of biofilm formation of $P$. aeruginosa was for $L$. plantarum. Abdelbasset et al. demonstrated that bacteriocins of lactic acid bacteria show broad antibacterial activity against Gram-negative bacteria [35]. Acid, lactic bacteria are most common bacteria that consider as a probiotic. These bacteria produce various low molecular mass components such as acids, carbon dioxide, alcohols, hydrogen peroxide, diacetyl, and other metabolites. Many of these components have a broad activity spectrum against other bacteria, and their production is largely affected by the food matrix itself [32]. Frostier et al. provided that the growth of some isolates isolated from clinical specimens such as $P$. aeruginosa was significantly reduced by staying near Lactobacillus spp. The colony count had decreased [41]. Valdez assessed the inhibition effect of $L$. plantarum on the pathogenicity of $P$. aeruginosa, which was isolated from a wound. The 
results illustrated that L. plantarum had an inhibition effect on the production of haemosiderin and lactoferrin elastase enzyme and biofilm formation. Also, the mice with burn infection, which infected by $P$. aeruginosa, treatment of these mice with Lactobacillus spp. recovered faster than control mice [42]. The interaction between pathogens and probiotics is strainrelated; therefore, extended study and other probiotics are required. It remains to be distinguished whether the inhibition effect in our study is species-specific or would have an effect on other pathogens.

Increasing consumption of industrial dairy products may reduce probiotics bacteria. However, the usage of probiotic bacteria may be useful for the prevention and treatment of some bacterial infections.

\section{Conclusions}

Our data demonstrate L. plantarum and L. casei isolated from the traditional dairy have the most biofilm inhibition effect and suggested the traditional dairy is one of the best probiotic foods against $P$. aeruginosa. Therefore, bacterial-mediated therapy could be considered a novel and effective treatment.

\section{Funding}

This research received no external funding.

\section{Acknowledgments}

This article was written based on a dataset of an M.Sc. thesis registered at Azad University of Zanjan, Iran.

\section{Conflicts of Interest}

The authors declare no conflict of interest.

\section{References}

1. Morsi El Soda, N.; Ahmed, N.; Omran, G. Isolation, identification and selection of lactic acid bacteria cultures for cheese making. Emirates Journal of Food and Agriculture 2003, 15, 51-71.

2. Rastegari, A.A.; Yadav, A.N.; Yadav, N. New and future developments in microbial biotechnology and bioengineering: Trends of microbial biotechnology for sustainable agriculture and biomedicine systems: perspectives for human health. Elsevier: 2020; https://doi.org/10.1016/C2019-0-00642-5.

3. Peng, K.; Koubaa, M.; Bals, O.; Vorobiev, E. Recent insights in the impact of emerging technologies on lactic acid bacteria: A review. Food Res. Int. 2020, 137, https://doi.org/10.1016/j.foodres.2020.109544.

4. Mora-Villalobos, J.A.; Montero-Zamora, J.; Barboza, N.; Rojas-Garbanzo, C.; Usaga, J.; Redondo-Solano, M.; Schroedter, L.; Olszewska-Widdrat, A.; López-Gómez, J.P. Multi-Product Lactic Acid Bacteria Fermentations: A Review. Fermentation 2020, 6, https://doi.org/10.3390/fermentation6010023.

5. Foddai, A.C.G.; Grant, I.R. Methods for detection of viable foodborne pathogens: current state-of-art and future prospects. Appl. Microbiol. Biotechnol. 2020, 104, 4281-4288, https://doi.org/10.1007/s00253-02010542-x.

6. Abdi, R.; Sheikh-Zeinoddin, M.; Soleimanian-Zad, S. Identification of lactic acid bacteria isolated from traditional Iranian Lighvan cheese. Pak. J. Biol. Sci. 2006, 9, 99-103, https://doi.org/10.3923/pjbs.2006.99.103.

7. Azadnia, P.; Khan Nazer, A. Identification of lactic acid bacteria isolated from traditional drinking yoghurt in tribes of Fars province. Iran. J. Vet. Res. 2009, 10, 235-240, https://doi.org/10.22099/IJVR.2009.1698.

8. Ebrahimi, M.T.; Ouweh, A.C.; Hejazi, M.A.; Jafari, P. Traditional Iranian dairy products: A source of potential probiotic lactobacilli. Afr. J. Microbiol. Res. 2011, 5, 20-27. 
9. Iranmanesh, M.; Ezzatpanah, H.; Mojgani, N.; Torshizi, M.A.K.; Aminafshar, M.; Maohamadi, M. Isolation of Lactic Acid Bacteria from Ewe Milk, Traditional Yoghurt and Sour Buttermilk in Iran. European Journal of Nutrition \& Food Safety 2012, 2, 79-92.

10. Mo, L.; Yu, J.; Jin, H.; Hou, Q.; Yao, C.; Ren, D.; An, X.; Tsogtgerel, T.; Zhang, H. Investigating the bacterial microbiota of traditional fermented dairy products using propidium monoazide with singlemolecule real-time sequencing. J. Dairy Sci. 2019, 102, 3912-3923, https://doi.org/10.3168/jds.2018-15756.

11. Tilocca, B.; Costanzo, N.; Morittu, V.M.; Spina, A.A.; Soggiu, A.; Britti, D.; Roncada, P.; Piras, C. Milk microbiota: Characterization methods and role in cheese production. J. Proteomics 2020, 210, https://doi.org/10.1016/j.jprot.2019.103534.

12. Islam, R.; Hossain, M.N.; Alam, M.K.; Uddin, M.E.; Rony, M.H.; Imran, M.A.S.; Alam, M.F. Antibacterial activity of lactic acid bacteria and extraction of bacteriocin protein. Advances in Bioscience and Biotechnology 2020, 11, 49-59, https://doi.org/10.4236/abb.2020.112004.

13. Coeuret, V.; Dubernet, S.; Bernardeau, M.; Gueguen, M.; Vernoux, J.P. Isolation, characterisation and identification of lactobacilli focusing mainly on cheeses and other dairy products. Le Lait 2003, 83, 269-306, https://doi.org/10.1051/lait:2003019.

14. Schulert, G.S.; Feltman, H.; Rabin, S.D.; Martin, C.G.; Battle, S.E.; Rello, J.; Hauser, A.R. Secretion of the toxin ExoU is a marker for highly virulent Pseudomonas aeruginosa isolates obtained from patients with hospital-acquired pneumonia. The Journal of infectious diseases 2003, 188, 1695-1706, https://doi.org/10.1086/379372.

15. Malhotra, S.; Hayes, D.; Wozniak, D.J. Cystic fibrosis and Pseudomonas aeruginosa: the host-microbe interface. Clin. Microbiol. Rev. 2019, 32, https://doi.org/10.1128/CMR.00138-18.

16. Ghorbani, H.; Memar, M.Y.; Sefidan, F.Y.; Yekani, M.; Ghotaslou, R. In vitro synergy of antibiotic combinations against planktonic and biofilm Pseudomonas aeruginosa. GMS Hygiene and Infection Control 2017, 12, https://doi.org/10.3205/dgkh000302.

17. Yekani, M.; Memar, M.Y.; Alizadeh, N.; Safaei, N.; Ghotaslou, R. Antibiotic Resistance Patterns of BiofilmForming Pseudomonas Aeruginosa Isolates from Mechanically Ventilated Patients. International Journal of Scientific Study 2017, 5, 84-88.

18. Gholizadeh, P.; Maftoon, H.; Aghazadeh, M.; Asgharzadeh, M.; Kafil, H.S. Current opinions in the infection control of carbapenem-resistant Enterobacteriaceae species and Pseudomonas aeruginosa. Rev. Med. Microbiol. 2017, 28, 97-103, https://doi.org/10.1097/mrm.0000000000000107.

19. Simova, E.; Beshkova, D.; Dimitrov, Z.P. Characterization and antimicrobial spectrum of bacteriocins produced by lactic acid bacteria isolated from traditional Bulgarian dairy products. J. Appl. Microbiol. 2009, 106, 692-701, https://doi.org/10.1111/j.1365-2672.2008.04052.x.

20. Kaktcham, P.M.; Zambou, N.F.; Tchouanguep, F.M.; El-Soda, M.; Choudhary, M.I. Antimicrobial and Safety Properties of Lactobacilli Isolated from two Cameroonian Traditional Fermented Foods. Sci. Pharm. 2012, 80, 189-203, https://doi.org/10.3797/scipharm.1107-12.

21. Sieladie, D.V.; Zambou, N.F.; Kaktcham, P.M.; Cresci, A.; Fonteh, F. Probiotic properties of lactobacilli strains isolated from raw cow milk in the western highlands of Cameroon. Innov. Rom. Food Biotechnol. 2011, 9, 12-28.

22. Bahar, Z.; Ghotaslou, R.; Taheri, S. In vitro anti-biofilm activity of Quercus brantii subsp. persica on human pathogenic bacteria. Research Journal of Pharmacognosy (RJP) 2017, 4, 67-73.

23. Musthafa, K.S.; Ravi, A.V.; Annapoorani, A.; Packiavathy, I.S.V.; Pandian, S.K. Evaluation of anti-quorumsensing activity of edible plants and fruits through inhibition of the $\mathrm{N}$-acyl-homoserine lactone system in Chromobacterium violaceum and Pseudomonas aeruginosa. Chemotherapy 2010, 56, 333-339, https://doi.org/10.1159/000320185.

24. Różalski, M.; Walencka, E.; Różalska, B.; Wysokińska, H. Antimicrobial activity of diterpenoids from hairy roots of Salvia sclarea L.: salvipisone as a potential anti-biofilm agent active against antibiotic resistant Staphylococci. Phytomedicine 2007, 14, 31-35, https://doi.org/10.1016/j.phymed.2005.10.008.

25. Ghotaslou, R.; Salahi, B. Effects of oxygen on in-vitro biofilm formation and antimicrobial resistance of Pseudomonas aeruginosae. Pharmaceutical Sciences 2013, 19, 96-99.

26. Kalishwaralal, K.; BarathManiKanth, S.; Pandian, S.R.K.; Deepak, V.; Gurunathan, S. Silver nanoparticles impede the biofilm formation by Pseudomonas aeruginosa and Staphylococcus epidermidis. Colloids Surf. B. Biointerfaces 2010, 79, 340-344, https://doi.org/10.1016/j.colsurfb.2010.04.014.

27. Kaneko, Y.; Thoendel, M.; Olakanmi, O.; Britigan, B.E.; Singh, P.K. The transition metal gallium disrupts Pseudomonas aeruginosa iron metabolism and has antimicrobial and antibiofilm activity. The Journal of clinical investigation 2007, 117, 877-888, https://doi.org/10.1172/jci30783.

28. Ghotaslou, R.; Bahari, Z.; Aliloo, A.; Gholizadeh, P.; Eshlaghi, B.S. The in vitro effects of silver nanoparticles on bacterial biofilms. The Journal of Microbiology, Biotechnology and Food Sciences 2017, 6, 1077-1080, https://doi.org/10.15414/jmbfs.2017.6.4.1077-1080.

29. Kavitha, P.; Sindhuja, D.; Banumathi, M. Isolation and Biochemical Characterization of Lactobacillus species Isolated from Dahi. Int. J. Curr. Microbiol. App. Sci 2016, 5, 1042-1049, https://doi.org/10.20546/ijcmas.2016.504.119. 
30. Wang, J.; Chen, X.; Liu, W.; Yang, M.; Zhang, H. Identification of Lactobacillus from koumiss by conventional and molecular methods. Eur. Food Res. Technol. 2008, 227, 1555-1561, https://doi.org/10.1007/s00217-008-0880-4.

31. Stepanović, S.; Vuković, D.; Dakić, I.; Savić, B.; Švabić-Vlahović, M. A modified microtiter-plate test for quantification of staphylococcal biofilm formation. J. Microbiol. Methods 2000, 40, 175-179, https://doi.org/10.1016/s0167-7012(00)00122-6.

32. Earnshaw, R.G. The antimicrobial action of lactic acid bacteria: natural food preservation systems. In: The Lactic Acid Bacteria. Springer: Volume 1, 1992; pp. 211-232.

33. Panel, E.F. Technical guidance-Update of the criteria used in the assessment of bacterial resistance to antibiotics of human or veterinary importance. EFSA Journal 2008, 6, https://doi.org/10.2903/j.efsa.2008.732.

34. Pal, V.; Jamuna, M.; Jeevaratnam, K. Isolation and characterization of bacteriocin producing lactic acid bacteria from a South Indian Special dosa (Appam) batter. Journal of culture collections 2005, 4, 53-60.

35. Abdelbasset, M.; Djamila, K. Antimicrobial activity of autochthonous lactic acid bacteria isolated from Algerian traditional fermented milk "Raïb". Afr. J. Biotechnol. 2008, 7, 2908-2914.

36. Ding, W.; Shah, N. Acid, bile, and heat tolerance of free and microencapsulated probiotic bacteria. J. Food Sci. 2007, 72, M446-M450, https://doi.org/10.1111/j.1750-3841.2007.00565.x.

37. Dunne, C.; O’Mahony, L.; Murphy, L.; Thornton, G.; Morrissey, D.; O’Halloran, S.; Feeney, M.; Flynn, S.; Fitzgerald, G.; Daly, C. In vitro selection criteria for probiotic bacteria of human origin: correlation with in vivo findings. The American journal of clinical nutrition 2001, 73, 386s-392s, https://doi.org/10.1093/ajcn/73.2.386s.

38. Vojtová, V.; Kolár, M.; Hricová, K.; Uvízl, R.; Neiser, J.; Blahut, L.; Urbánek, K. Antibiotic utilization and Pseudomonas aeruginosa resistance in intensive care units. New Microbiol. 2011, 34, 291-298.

39. Boris, S.; Jiménez-Díaz, R.; Caso, J.; Barbes, C. Partial characterization of a bacteriocin produced by Lactobacillus delbrueckii subsp. lactis UO004, an intestinal isolate with probiotic potential. J. Appl. Microbiol. 2001, 91, 328-333, https://doi.org/10.1046/j.1365-2672.2001.01403.x.

40. Coconnier, M.-H.; Liévin, V.; Bernet-Camard, M.-F.; Hudault, S.; Servin, A.L. Antibacterial effect of the adhering human Lactobacillus acidophilus strain LB. Antimicrob. Agents Chemother. 1997, 41, 1046-1052, https://doi.org/10.1128/AAC.41.5.1046.

41. Forestier, C.; Guelon, D.; Cluytens, V.; Gillart, T.; Sirot, J.; De Champs, C. Oral probiotic and prevention of Pseudomonas aeruginosa infections: a randomized, double-blind, placebo-controlled pilot study in intensive care unit patients. Critical Care 2008, 12, https://doi.org/10.1186/cc6907.

42. Valdez, J.; Peral, M.; Rachid, M.; Santana, M.; Perdigon, G. Interference of Lactobacillus plantarum with Pseudomonas aeruginosa in vitro and in infected burns: the potential use of probiotics in wound treatment. Clin. Microbiol. Infect. 2005, 11, 472-479, https://doi.org/10.1111/j.1469-0691.2005.01142.x. 